\title{
Presence of the deep-bodied pipefish, Leptonotus blainvilleanus (Eydoux \& Gervais, 1837) [Syngnathiformes: Syngnathidae], in San Jorge Gulf, Patagonia, Argentina
}

\author{
Guillermo M. Caille ${ }^{1,2^{*}}$, Ariana Apezteguia ${ }^{1}$, Daniel Vaquero ${ }^{1},{\text { Pablo } \text { Cochia }^{2}}^{2}$ \\ ${ }^{1}$ Fundación Patagonia Natural, Puerto Madryn, Argentina; *Corresponding Author: gcaille2003@yahoo.com.ar \\ ${ }^{2}$ Ciencias Naturales, Universidad Nacional de la Patagonia, Trelew, Argentina
}

Received 27 February 2012; revised 10 March 2012; accepted 1 April 2012

\begin{abstract}
This short report communicates the finding of a Deep-bodied pipefish, Leptonotus blainvilleanus, (Eydoux \& Gervais, 1837) [Syngnathiformes, Syngnathidae] in shallow waters of the San Jorge Gulf, Patagonia Argentina, in August 2010. It's a new record for its known distribution range in the coast of South America. Photos and videos are available.
\end{abstract}

Keywords: Pipefish; Syngnathidae; Leptonotus balainvilleanus; San Jorge Gulf; Coastal Cold-Temperate Waters; Patagonia Argentina

This note communicates the finding, on August 7, 2010, of a Deep-bodied pipefish, Leptonotus blainvilleanus (Eydoux \& Gervais, 1837) (Syngnathiformes, Syngnathidae) [1,2]; in shallow waters of the San Jorge Gulf (Argentina); about 20 kilometers to the South of the town of Rada Tilly ( $46^{\circ} 2^{\prime} 30.32^{\prime \prime} S$ - $67^{\circ} 35^{\prime} 45.02^{\prime \prime} \mathrm{W}$, see Figure 1).

Leptonotus blainvillanus presents a distribution that runs from the South of Brazil (in the Atlantic) to the South of Chile (in the Pacific). They are benthic fish, generally found in algae beds in estuaries or coastal areas. They are difficult to see, since they are easily confused with algae. They feed on small crustaceans and small fish. They are ovoviviparous, and the male carries the eggs in a brood pouch which is found under the tail [3].

The specimen, a male of about 20 centimeters of total length (see Figure 2), was found swimming near the bottom, in a tidal channel. At the time the water had a temperature of $6^{\circ} \mathrm{C}$, and the depth did not exceed 3 meters. The fish was swimming in a vertical position, and photos and videos were taken before releasing it (photos and videos are available; contact:

ari_apezteguia@yahoo.com.ar).
This finding confirms the presence of Leptonotus blainvilleanus in waters of the San Jorge Gulf; resulting in a new record for its known distribution range [4]; as in South America it has been reported in coastal waters, up to 25 meters depth, on the southwest coast of the Atlantic, South to the San José Gulf (Argentina, 42 $30^{\prime}$ S); and it is estimated that it reaches at least to the North of Chile and possibly to the South of Peru in the Southeast Pacific [5] (See Figure 3).

Although the conservation status of $L$. blainvillanus still has not been assessed by the IUCN, it's found in shallow waters of San Jorge Gulf, whose coastal environment is well preserved and with abundant seaweed beds, suggesting that it could support persistent populations of the

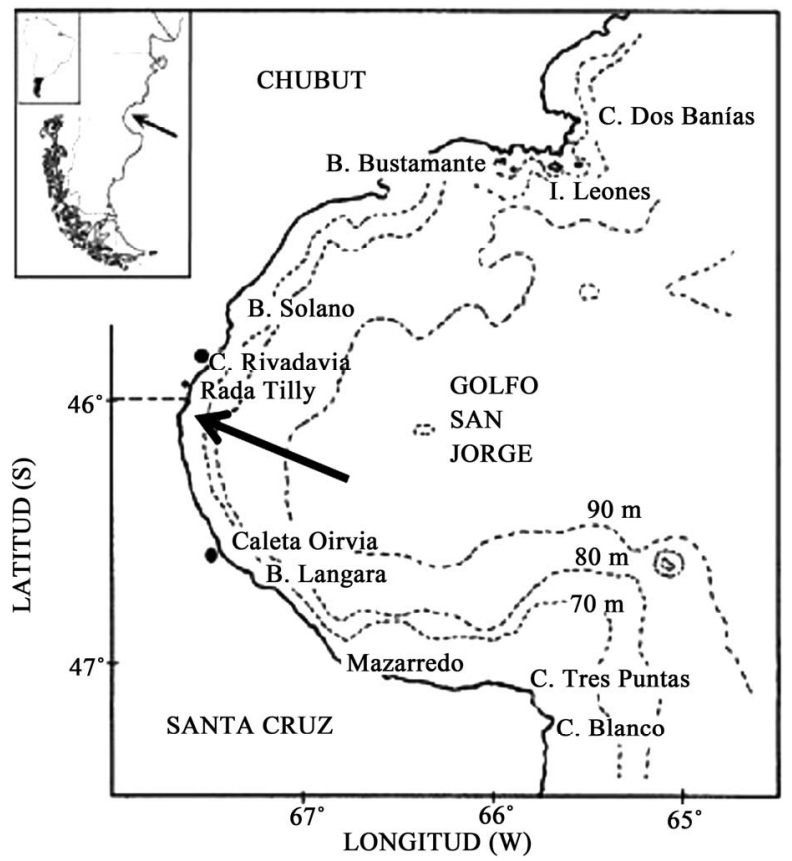

Figure 1. Site where the specimen of L. blainvilleanus was found in August 2010. 


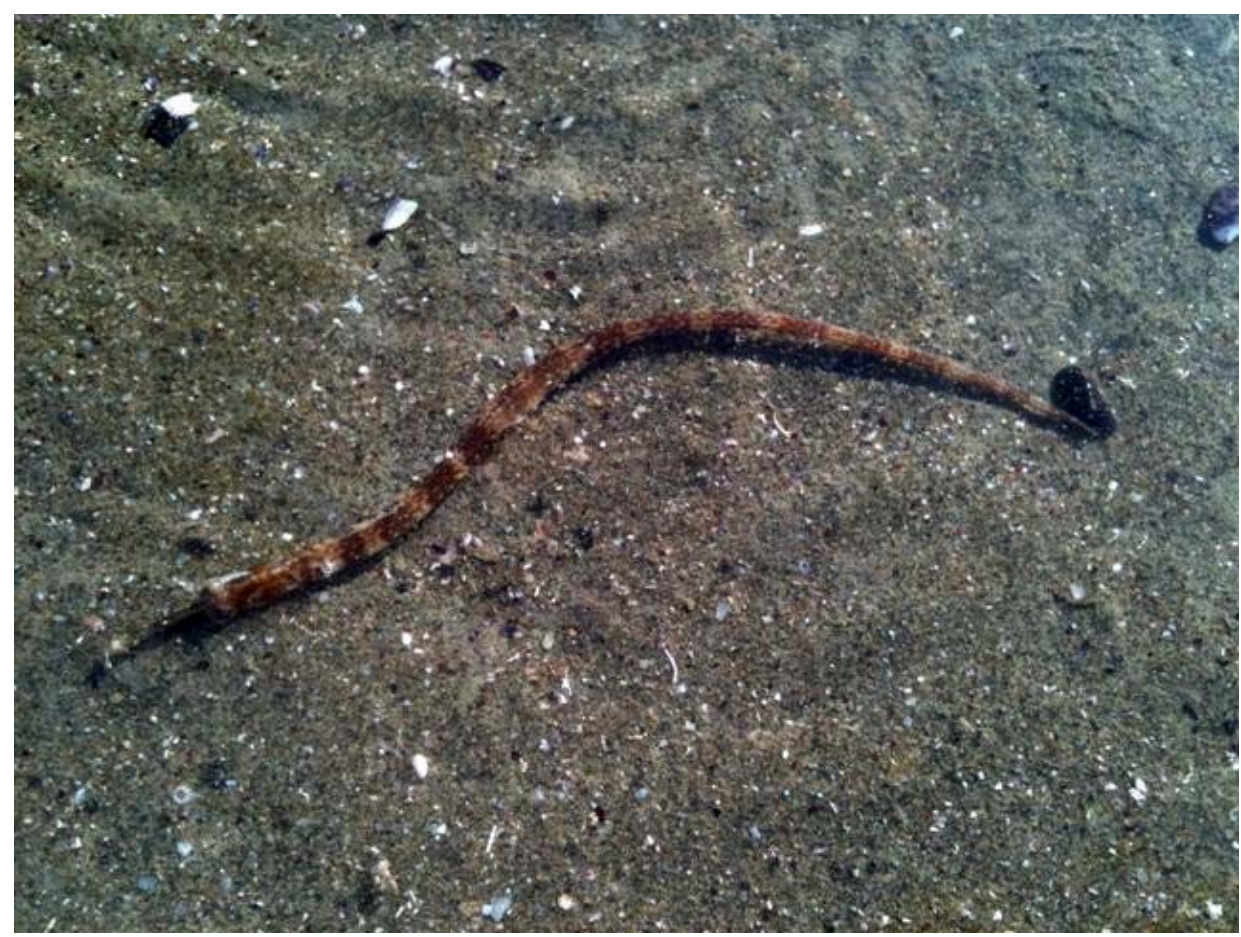

Figure 2. Picture of the specimen of Leptonotus blainvilleanus found in August 2010.

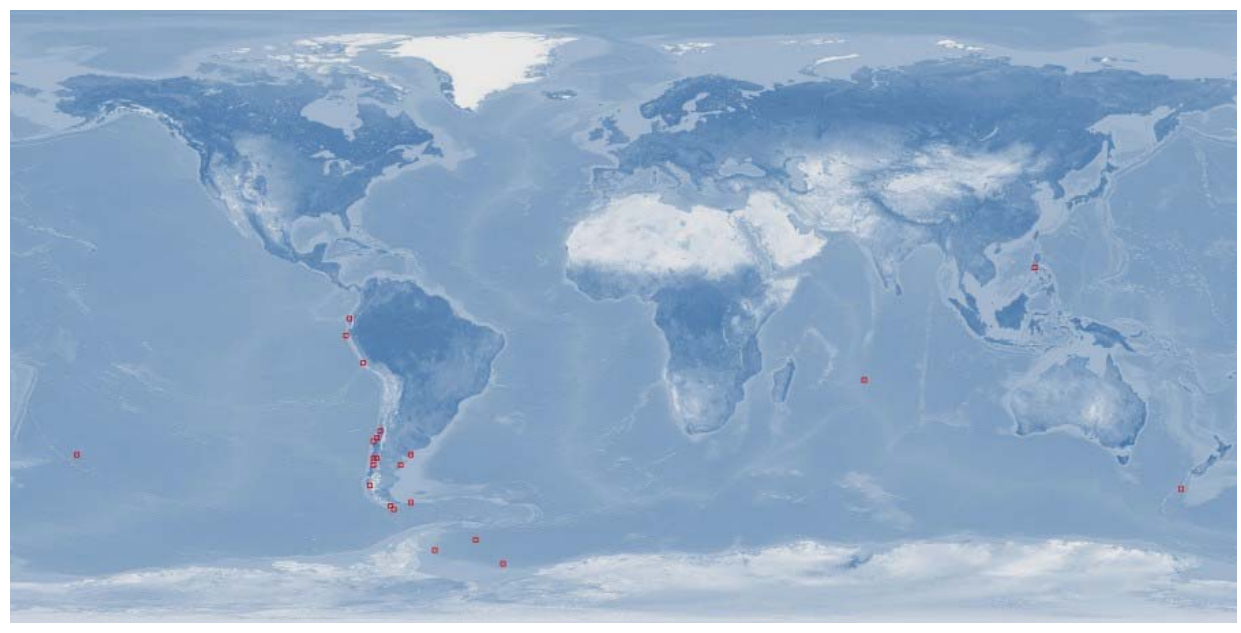

Figure 3. Computer generated map for Leptonotus blainvilleanus (www.aquamaps.org. Web accessed 26 December 2011).

species. Confirming this report, a second specimen was found in April 2011, near Punta del Marqués (4557'14.53"S - $67^{\circ} 32^{\prime} 17.02^{\prime \prime W}$ ), swimming between meadows of seaweed at about 8 meters of depth.

\section{REFERENCES}

[1] Eschmeyer, W. (2010) Catalog of fishes. California Academy of Sciences Research, San Francisco.

http://research.calacademy.org/redirect?url=http://researchar chive.calacademy.org/research/Ichthyology/catalog/fishcat $\underline{\text { main.asp }}$
[2] Lourie, S.A., Vincent, A.C.J. and Hall, H.J. (1999) Seahorses: An identification guide to the world's species and their conservation. Project Seahorse, London.

[3] Breder, C.M. and Rosen, D.E. (1966) Modes of reproduction in fishes. T. F. H. Publications, Inc., Neptune City.

[4] Dawson, C. E. (1985) Indo-pacific pipefishes (Red Sea to the Americas). Gulf Coast Research Laboratory, Ocean Springs.

[5] Froese, R. and Pauly, D. (2011) FishBase. World Wide Web Electronic publication.

http://www.fishbase.org/Summary/speciesSummary.php?I $\underline{\mathrm{D}=12858 \text { \&genusname}=\text { Leptonotus\&speciesname=blainv }}$ illeanus\&AT=Leptonotus+blainvilleanus\&lang=English 